\title{
Performance, carcass and meat quality of Angus-Nellore heifers finished in integrated livestock forest systems
}

\author{
F. de Oliveira Neves ${ }^{1,3}$, C. Andrighetto', P. Aparecida da Luz', G. Pavan Mateus ${ }^{2}$, J. Mara de Freitas \\ Santos $^{1}$, L. Pereira de Lima ${ }^{1}$, B. Midori Souza Sekiya ${ }^{1}$, L.H. Zanetti', G.C. Lupatini ${ }^{1}$ and N.C. Vieira ${ }^{1}$ \\ ${ }^{1}$ State University (UNESP), College of Agricultural and Technological Sciences, \\ Comandante João Ribeiro de Barros Road km 651, 17900-000 Dracena, Brazil \\ ${ }^{2}$ São Paulo State Agribusiness Technology Agency, Nemezião de Souza Pereira Road km 6, 16900-000 Andradina, Brazil
}

KEY WORDS: industrial crossing, longissimus thoracis, silvopastoral systems, tenderness, weight gain

Received: 20 February 2020

Revised: 17 February 2021

Accepted: 18 February 2021

${ }^{3}$ Corresponding author:

e-mail: franciely.neves@hotmail.com
ABSTRACT. The objective of this research was to evaluate the impact of the different shading densities on performance, carcass and meat quality of AngusNellore heifers finished in a conventional system (CS) and integrated livestock forest (ILF) system with two different densities of eucalyptus trees (ILF-1: 187 and ILF-2: 446 trees/ha). Seventy-two heifers were randomly assigned to three groups, and the animal performance was evaluated during the finishing phase. Forty-eight samples of the longissimus thoracis muscle were collected for the analysis of carcass and meat quality. No differences were found between treatments for final live weight and average daily gain $(P>0.05)$. The weight gain per ha and carcass weight gain per ha was lower in ILF-2 system in comparison to CS system, which did not differ from ILF-1. However, the stocking rate was higher in CS in comparison to that of the ILF-1 and ILF-2 systems $(P<0.05)$. Microclimatic variables and thermal comfort indices were better in ILF-1 and ILF-2 systems, except for the wind speed that was higher in CS due to the absence of trees $(P<0.05)$. Carcass and meat quality did not differ between the evaluated systems $(P>0.05)$. Only the $\mathrm{pH}$ and protein content showed a difference $(P<0.05)$, but both were within the appropriate range warranting the meat good quality. It is thus concluded that the system with lower tree density does not interfere with the performance and carcass characteristics of heifers. In addition, the systems with trees provide better comfort to the animals and do not affect the quality of their carcass and meat.

\section{Introduction}

Brazil is currently the leader among the countries with the largest commercial cattle herds ( $214.69 \mathrm{mln}$ heads) and is the largest exporter of beef $(8.2 \mathrm{mln} \mathrm{t}$ of meat produced and $1.4 \mathrm{mln} \mathrm{t}$ of meat exported), which is a significant global achievement, with $13 \%$ increase in slaughtered heads in 2018 as compared to the previous year (ANUALPEC, 2018).

Eighty-four percent of the total heads slaughtered were fed and finished exclusively on pasture, mainly in tropical conditions. Brazilian beef production is based on forage, which is the most economical and practical way of producing and offering food for animals (ANUALPEC, 2018). Pastures in Brazil, however occupy a large area, are still degraded ( $\sim 80 \mathrm{mln}$ ha) (Crusciol et al., 2014).

Therefore, the integrated crop livestock forest systems (ICFS), in their different formats, can constitute a viable alternative in finding a way to combine the increased demand in the expansion of global production of environmentally appropriate 
products with the urgent need for sustainable agriculture (Wirsenius et al., 2010).

The integrated livestock forest system, which integrates the livestock and forestry component, provides, among other benefits, comfort to the animals through the presence of the shaded areas under trees. The stress caused by excessive heat influences performance, thermal comfort and behaviour of the animals, thus affecting the quality of the carcass and meat. The last two are affected in different ways: a) muscle metabolism under high temperatures is changing and so the quality of meat is influenced; b) exposition to high temperatures requires from animals strategies facilitating heat dissipation, which can persist after slaughter and have consequences on carcass composition and meat quality (Gregory, 2010).

Recently, no difference was observed in the quality of carcass and meat between the crop-livestock integration systems and crop-livestock-forest integration systems with two tree densities (Luz et al., 2019). However, the above study evaluated Nellore cattle, leaving doubts about the impact of integrated systems (with the presence of trees) for crossbred cattle (Bos taurus $\times$ Bos indicus), which have been used by to improve marbling and carcass quality (Pereira et al., 2017).

In addition, little is known about the adaptive patterns and productive responses of these genetic groups, the products of their crossbreeding and the quality of the final product to the climatic conditions in which they are raised in Brazil. Thus, the objective of this study was to evaluate the impact of the presence of different shading densities on the performance, carcass and meat quality of Angus-Nellore heifers in conventional system (CS; with no forest component) and integrated livestock-forest (ILF) system with two densities of eucalyptus trees (187 and 446 trees per ha for ILF-1 and ILF-2, respectively).

\section{Material and methods}

The experiment was carried out according to the ethical principles for animal tests (Protocol No. 03/2017.R1 - CEUA) determined by the Ethics Committee on the Use of Animals (CEUA) of the College of Agricultural and Technological Sciences - Unesp, Dracena Campus.

\section{The experimental site and climatic conditions}

The experiment was carried out at the São Paulo State Agribusiness Technology Agency, Regional Pole for Technological Development of the Far West Region, located in the city of Andradina, São Paulo
State $\left(20^{\circ} 53^{\prime} 46^{\prime \prime} \mathrm{S}\right.$ latitude, $51^{\circ} 22^{\prime} 46^{\prime}$ 'W longitude, at a height of $405 \mathrm{~m}$ ). According to the Köppen classification, the predominant climate in the region is Aw (tropical climate with dry winter).

According to climatic data from the meteorological station (APTA), the annual rainfall in the region is around $1.257 \mathrm{~mm}$, with $78 \%$ occurring from October to April and 22\% from May to September, which corresponds to the dry season.

\section{Area history}

The implementation of the system started in December 2011, when the area was selected and the topographic survey was carried out. The outline of the experiment was shaped in the first half of 2012, with the choice of treatments and division of the paddocks. The soil in the experimental area was classified as dystrophic Red Yellow Argisol, with an average terrain slope of $6 \%$. In the second half of 2012, soil sampling and analysis, soil preparation, liming, fertilization and treatment scheduling were carried out in order to start planting eucalyptus trees.

In July 2012, the soil was corrected based on chemical analysis $(0-20 \mathrm{~cm})$, which showed the following attributes: $\mathrm{pH}\left(\mathrm{CaCl}_{2}\right)$ 4.8; organic matter $16 \mathrm{~g} / \mathrm{dm}^{3} ; \mathrm{P}$ (resin) $3 \mathrm{mg} / \mathrm{dm}^{3} ; \mathrm{K}^{+}, \mathrm{Ca}^{2+}, \mathrm{Mg}^{2+}$ and $\mathrm{H}^{+} \mathrm{Al} 1.9,7,5$ and $20 \mathrm{mmolc} / \mathrm{dm}^{3}$, respectively, $\mathrm{S}-\mathrm{SO}_{4}{ }^{2-} 1 \mathrm{mg} / \mathrm{dm}^{3}$ and $\mathrm{V} \%$ (base saturation) of $42 \%$. The contents of clay, silt and sand were 107, 113 and $780 \mathrm{~g} / \mathrm{kg}$, respectively. A dolomitic limestone (PRNT 80\%) was applied by broadcasting in an average amount of $1200 \mathrm{~kg} / \mathrm{ha}$ in order to increase saturation by bases by $70 \%$, and agricultural plaster was applied to the whole area in the amount of $600 \mathrm{~kg} / \mathrm{ha}$ in order to provide sulphur to cultures, as recommended by Bulletin 100 (van Raij et al., 1997) for the State of São Paulo. As part of soil preparation, terracing, harrowing, plowing and levelling were carried out.

The trees were planted from November 2012 to March 2013 through manual planting of seedlings, following the level lines present in the area. The eucalyptus clone used for planting was Eucalyptus urograndis I-224 with an emphasis on the production of cellulose.

For fertilization of the planted trees, $350 \mathrm{~kg} / \mathrm{ha}$ of the 04-30-16 formula were used, with quantity of 210 g per seedling $\left(8.4 \mathrm{~g} \mathrm{~N}, 63 \mathrm{~g} \mathrm{P}_{2} \mathrm{O}_{5}, 33.6 \mathrm{~g} \mathrm{~K}_{2} \mathrm{O}\right)$ in each planting pit. During the topdressing, carried out in February 2013, $37 \mathrm{~kg} / \mathrm{ha}$ of N, $3 \mathrm{~kg} / \mathrm{ha}$ of $\mathrm{Zn}$ and $2 \mathrm{~kg} / \mathrm{ha}$ of B were used, applying $50 \mathrm{~g}$ of urea $(23 \mathrm{~g} \mathrm{~N}), 9 \mathrm{~g}$ of $\mathrm{Zn}$ sulphate $(1.8 \mathrm{~g} \mathrm{Zn})$ and $12 \mathrm{~g}$ of borogran $(1.2 \mathrm{~g} \mathrm{~B})$ over each eucalyptus seedling. 
The sowing of soyabeans (cultivar BMX Power) was carried out in December 2012 in all agricultural integration systems using a Semeato model SAM 200 seeder (Semeato S/A Industry and Commerce, Passo Fundo, Brazil) with four rows, with a density of 20 seeds per meter and a spacing of $0.50 \mathrm{~m}$ between lines, totalling 400000 seeds/ha. The seeds were fertilized by $300 \mathrm{~kg}$ of mineral fertilizer per ha in a 4-30-16 scheme, corresponding to the application of $12 \mathrm{~kg} / \mathrm{ha}$ of N, $90 \mathrm{~kg} / \mathrm{ha}$ of $\mathrm{P}_{2} \mathrm{O}_{5}$ and $48 \mathrm{~kg} / \mathrm{ha}$ of $\mathrm{K}_{2} \mathrm{O}$. The topdressing fertilization was carried out 40 days after planting, applying $200 \mathrm{~kg} / \mathrm{ha}$ according to the 00-20-20 formula. The harvesting was carried out in May 2013.

In the 2013/2014 harvest, maize with Marandu grass were cultivated in December, using the DKB 390 maize hybrid with a spacing of $0.80 \mathrm{~m}$ between lines and fertilization with $350 \mathrm{~kg} / \mathrm{ha}$ of the 8-2816 formula, which corresponds to $28 \mathrm{~kg} / \mathrm{ha}$ of $\mathrm{N}$, $98 \mathrm{~kg} / \mathrm{ha}$ of $\mathrm{P}_{2} \mathrm{O}_{5}$ and $56 \mathrm{~kg} / \mathrm{ha}$ of $\mathrm{K}_{2} \mathrm{O}$, with topdressing using $112 \mathrm{~kg} / \mathrm{ha}$ of $\mathrm{N}$ via urea. The forage used was Urochloa brizantha (Syn. Brachiaria brizantha) $\mathrm{cv}$. Marandu, forming a grass cover with a density of $10 \mathrm{~kg} / \mathrm{ha}$ of pure and viable seeds using a no-till seeder. Maize was harvested for silage in March 2014 and the pasture was closed until October of the same year.

In January 2015, the first cycle of beef cattle production began, in which weaned Nellore calves were used until fattening, with the experiment ending in July 2016. The second cycle started in March 2017 with the rearing phase of the animals. The finishing phase, which comprises the present study, started on April 4, 2018, when heifers were approximately 19 months old and had an average initial weight of $392.1 \mathrm{~kg}$. On June 14, 2018 animals with the average weight of $432.9 \mathrm{~kg}$ were slaughtered in a commercial slaughterhouse.

The eucalyptus trees had height of $17.01 \mathrm{~m}$ and $18.89 \mathrm{~m}$ for ILF-1 and ILF-2, respectively. The circumference at breast height was of 61.04 and $57.32 \mathrm{~cm}$ for ILF-1 and ILF-2, respectively, and the diameter at breast height was 19.43 and $18.21 \mathrm{~cm}$ for ILF-1 and ILF-2, respectively.

\section{Animals, treatments, pasture management and supplementation}

Seventy-two Angus-Nellore heifers were used, distributed in randomized blocks by weight ranges and divided into the following treatments: conventional system (CS) with Marandu grass and no forest component; integrated livestock forest system (ILF-1), with eucalyptus trees planted in simple lines and distance between the lines from 17 to $21 \mathrm{~m}$, the distance between trees of $2 \mathrm{~m}$ and density of 187 trees/ha; integrated livestock forest system (ILF-2), with eucalyptus trees planted in triple rows, with the distance between rows of eucalyptus of $3 \mathrm{~m}$, the distance between plants of $2 \mathrm{~m}$, the distance between the eucalyptus lines from 17 to $21 \mathrm{~m}$ and density of 446 trees/ha.

The adopted grazing method was continuous stocking with variable stocking rate, using the put and take technique (Mott and Lucas, 1952). In each paddock, 6 tester animals and variable number of regulators were used, according to the need of adjusting the stocking rate in order to maintain the management goal, with 27, 28.3 and $28.4 \mathrm{~cm}$ for CS, ILF-1 and ILF-2, respectively (the average is exactly within the range of 15 to $30 \mathrm{~cm}$, maintaining good pasture conditions and greater performance per animal) (Euclides et al., 2014).

The supplement consumption was $0.7 \%$ of live weight $(16 \%$ of crude protein $(\mathrm{CP})$ and $75 \%$ of total digestible nutrients (TDN)), provided throughout the experimental period. Potensal ${ }^{\circledR}$ (Facholi sementes e nutrição animal, Santo Anastácio, Brazil) feed was provided daily at 11:00 (Table 1).

Table 1. Composition of the BR BEEF 16 Potensal $^{\circledR}$ ration (Facholi sementes e nutrição animal, Santo Anastácio, Brazil) offered from April to June, the finishing phase

\begin{tabular}{lc}
\hline Nutrient & Quantity, kg \\
\hline Cobalt (min.), mg & 1.10 \\
Copper (min.), mg & 40.00 \\
lodine (min.), mg & 3.00 \\
Mannan oligosaccharides (min.), mg & 500.00 \\
Manganese (min.), mg & 105.00 \\
Mineral Matter (max.), mg & 100.00 \\
Selenium (min.), mg & 0.72 \\
Zinc (min.), mg & 105.00 \\
Calcium (max.), g & 15.00 \\
Calcium (min.), g & 12.00 \\
Sulfur (min.), g & 2.70 \\
Ethereal extract (min.), g & 30.00 \\
ADF (max.), g & 68.00 \\
Gross fiber (max.), g & 100.00 \\
Phosphorus (min.), g & 6.00 \\
Magnesium (min.), g & 2.60 \\
Sodium Monensin (min.), g & 70.00 \\
TDN estimated (min.), g & 750.00 \\
NPN - Equiv. Prot. (max.), g & 36.50 \\
Crude protein (min.), g & 160.00 \\
Sodium (min.), g & 5.00 \\
Moisture (max.), g & 120.00 \\
Vitamin A (min.), IU & 16000 \\
Vitamin D (min.), IU & 200 \\
Vitamin E (min.), IU & 50000 \\
\hline ADF - acid detergent fibe;
\end{tabular}

ADF - acid detergent fibre; TDN - total digestible nutrients; NPN - non-protein nitrogen; composition according to producer information 


\section{Forage mass assessment}

The measurement of forage mass was carried out every 28 days, using all material present within the frame measuring $1 \times 0.5 \mathrm{~m}\left(0.5 \mathrm{~m}^{2}\right)$, collected at 9 points of each paddock at around the average height for the experimental unit with the help of a brush cutter. The cut forage was weighed and homogenized. The sample was then weighed and taken to the oven with forced air circulation in order to determine the partially dry matter at $65{ }^{\circ} \mathrm{C}$ until it reached constant weight, when the dry forage mass was calculated. The stocking rate (SR) was calculated using the average weight of the tester animals and the number of days, during which the animals stayed in the pasture.

In the beginning of the experiment, the bromatological analysis of the forage, was done and the results are presented in Table 2. We have used the grazing simulation, with identification of the locations and parts of the plant selected by the animals throughout the experimental plot and then simulating manually the process of picking and harvesting of forage, according to the methodology described by Johnson (1978).

Table 2. Bromatological composition of the Urochloa brizantha cv. Marandu, \%

\begin{tabular}{llrllll}
\hline Treatment $^{1}$ & DM & \multicolumn{1}{c}{ CP } & NDF & ADF & LIG & MM \\
\hline CS & 32.90 & 9.90 & 67.34 & 32.79 & 3.25 & 7.10 \\
ILF-1 & 30.99 & 12.32 & 66.93 & 34.09 & 3.25 & 7.48 \\
ILF-2 & 30.55 & 12.00 & 66.94 & 34.55 & 3.15 & 7.69 \\
\hline
\end{tabular}

${ }^{1}$ treatments: CS - conventional system, ILF-1 - integrated livestock forest system with a density of 187 trees/ha, ILF-2 - integrated livestock forest system with a density of 446 trees/ha; DM - dry matter, $\mathrm{CP}$ - crude protein, NDF - neutral detergent fibre, ADF - acid detergent fibre, LIG - lignin, MM - mineral matter

\section{Animal performance}

Weighing was carried out every 28 days, with prior solid fasting for $14 \mathrm{~h}$. The average daily gain (ADG) was obtained by the difference between the results of the final and initial weighing, divided by the number of days in the period. Weight gain per area (hectare) (WGA) was calculated by multiplying the ADG by the average number of animals per ha and the number of grazing days. The carcass weight gain per ha (CWG) was calculated as follows: live weight gain $\times$ carcass yield.

\section{Microclimatic variables and thermal comfort indexes}

The following microclimatic variables were obtained of the treatments: wind speed through anemometer (WS), air temperature (AT), relative humidity (RH) and globe temperature (GT), which were recorded hourly, using dataloggers coupled to black globes. In the CS the equipment was placed in the sun, while in ILF systems the equipment remained in the shade. The equipment was installed at $1.4 \mathrm{~m}$ from the ground, simulating the height of the center of mass of large ruminants. The evaluations were carried on April 20, 2018 and May 20, 2018 and the presented data are average of the two evaluations. With these data, the following thermal comfort indexes were calculated:

- Temperature and Humidity Index (THI) with the equation proposed by Thom (1959):

$$
\mathrm{THI}=\mathrm{at}+0.36 \mathrm{dpt}+41.5
$$

where: at - ambient temperature and $\mathrm{dpt}-\mathrm{dew}$ point temperature;

- Globe Temperature and Humidity Index (GTHI) with the equation proposed by Buffington et al. (1981):

$$
\mathrm{GTHI}=\mathrm{gt}+0.36 \mathrm{dpt}+41.5
$$

where: gt - black globe temperature and dpt - dew point temperature.

\section{Slaughter and collection of samples}

At the end of the experiment, the heifers were weighed and sent to the slaughterhouse, located in Bariri, Sao Paulo, $370 \mathrm{~km}$ from Dracena. During slaughter, the carcasses were identified, weighed individually to determine the hot carcass weight $(\mathrm{HCW})$ and carcass yield $(\mathrm{CY}),(\mathrm{CY}=\mathrm{HCW} /$ slaughter weight $\times 100$ ). Then, the visceral fat was collected and weighed.

After that, the carcasses were taken to a cold chamber and, $24 \mathrm{~h}$ later, samples of the longissimus thoracis muscle were collected and transported in thermal boxes with ice from the refrigerator to the Laboratory of Technology and Meat Science at Unesp (Dracena Campus). Cross-sectional cuts of approximately $2.5 \mathrm{~cm}$ were made between $12^{\text {th }}$ and $13^{\text {th }}$ ribs using a BECCARO band saw model 255 (Beccaro industrial machines Ltda, Rio Claro, Brazil) for the analysis of rib eye area, subcutaneous fat thickness, marbling, $\mathrm{pH}$, colour, cooking weight loss and shear force, as well as for the approximate composition and collagen.

\section{Rib eye area, subcutaneous fat thickness and marbling}

For rib eye area (REA) and subcutaneous fat thickness (SFT) measurements the piece was photographed and measured using the Image $\mathrm{J}$ software (National Institutes of Health, Bethesda, MD, USA). The methodology described by the USDA Quality Grade (2017) was used to determine the marbling (MAR) score, with scores ranging 
from 1 to 10 where; $1=$ practically devoid, $2=$ traces, $3=$ slight, $4=$ small, $5=$ modest, $6=$ moderate, $7=$ slightly abundant, $8=$ moderately abundant, $9=$ abundant and $10=$ very abundant.

\section{Potential of hydrogen $(\mathrm{pH})$ and meat colour}

The $\mathrm{pH}$ was determined by means of a direct puncture with a coupled thermometer (Model HI 99163; Hanna Instruments, Woonsocket, RI, USA), previously calibrated with buffer solutions of pH 4.0 and 7.0 (Merck, Darmstadt, Germany), according to the method proposed by Béltran et al. (1997).

The colour of the meat was determined by colorimeter (CR-410-Konica Minolta, Camera Co., Ltd., Osaka, Japan) at three different readings of muscles. The readings were carried out in accordance with the CIELAB system, registering light reflectance in three dimensions: $L^{*}$ (luminosity), $a^{*}$ (redness) and $b^{*}$ (yellowness), according to the methodology described by Honikel (1998).

Determination of the values for the tint angle $\left(H^{*}\right)$ was obtained according to MacDougall (1994) and the determination of the oxymyoglobin and metmyoglobin content present on the meat surface $(\mathrm{O} / \mathrm{M})$ was carried out according to Olivo and Shimokomaki (2001), using the coordinates of red content $\left(a^{*}\right)$ and yellow intensity $\left(b^{*}\right)$, obtained when analysing colorimetric data using the following formulas: $H^{*}=\tan ^{-1}\left(b^{*} / a^{*}\right) ; \mathrm{O} / \mathrm{M}=$ $(a * / b *)$.

\section{Weight loss by cooking, shear force and collagen content}

For the determination of weight loss by cooking (WLC), each sample was weighed and then placed on electric plate, preheated to $170{ }^{\circ} \mathrm{C}$, until the temperature of the geometric centre of each sample reached $72{ }^{\circ} \mathrm{C}$, with the later measured by means by digital skewer thermometer. The sample was then removed from the electric plate, cooled to room temperature $\left(25^{\circ} \mathrm{C}\right)$, measured using an infrared thermometer, and then weighed again to determine the WLC, which was calculated by the difference in weight of the sample before and after being subjected to thermal treatment, and expressed as $\%$.

The shear force (SF) test was performed using the WLC samples after refrigeration at $4{ }^{\circ} \mathrm{C}$ for $12 \mathrm{~h}$. Eight cylinders of tissue with $1.27 \mathrm{~cm}$ in diameter were removed with the help of a bench drill from each sample, and then placed with the fibres oriented perpendicular to the blades of the Texturometer device (TA-SBA CT3, Brookfield AMETEK, Middleboro,
MA, USA). The device descended at a speed of $20 \mathrm{~cm} / \mathrm{min}$ (AMSA, 1995).

For the analysis of collagen, the near infrared spectroscopy (NIRS) methodology was used by means of ISIscan-FoodScan ${ }^{\mathrm{TM}}$ software (Foss Brazil, São Paulo, Brazil).

\section{Centesimal composition}

To determine the centesimal composition, NIRS methodology was used by means of ISIscanFoodScan $^{\mathrm{TM}}$ software to evaluate the approximate composition (method 2007.04; AOAC International, 2012). The ashes were determined according to the method (no. 39.1.09) recommended by AOAC International (2007).

\section{Experimental design and analysis of results}

The experimental design consisted of randomized blocks, with three treatments and four repetitions per treatment. The blocking criterion was based on the weight of animals.

For the performance variables, 24 animals were used per treatment ( 6 animals per paddock $\times$ 4 repetitions per paddock $\times 3$ treatments), in total 72 animals and, for meat and carcass analyses, 16 animals were used per treatment ( 4 animals per paddock $\times 4$ repetitions per paddock $\times 3$ treatments), in total 48 animals, the paddock being, in both cases, the experimental unit.

The data were analysed by SAS 9.4 (SAS Institute Inc., Cary, NC, USA). The UNIVARIATE NORMAL procedure was used and the normality of the data was confirmed by the Shapiro-Wilk test $(\mathrm{W} \geq 0.90)$. Data were analysed using the PROC MIXED procedure and the Satterthwaite approximation to determine the degrees of freedom for fixed effects tests. Both the system and the block were considered fixed effects, while the paddock was a random variable. The average values were calculated by the lsmeans procedure, and the results are reported as least squares and separated using the difference probability option (pdiff). To examine the differences between treatments the Tukey test was used. The effects were considered statistically significant at $P<0.05$.

\section{Results}

According to the performance results, there were no differences $(P>0.05)$ between the different treatments for final live weight (FLW) and ADG. Although there was no statistical difference in the ADG, there was difference in weight gain 
Table 3. Final live weight (FLW), average daily gain (ADG), stocking rate (SR), weight gain per area (WGA) and carcass weight gain (CWG) of Angus-Nellore heifers under grazing conditions in conventional system (CS), integrated livestock forest with a density of 187 (ILF-1) and 446 (ILF-2) trees/ha, supplemented from April to June

\begin{tabular}{cccccc}
\hline Indices & $\begin{array}{l}\mathrm{FLW}, \\
\mathrm{kg}\end{array}$ & $\begin{array}{l}\text { ADG, } \\
\mathrm{kg} / \mathrm{d}\end{array}$ & $\begin{array}{l}\mathrm{SR}, \\
\mathrm{kg} / \mathrm{ha}\end{array}$ & $\begin{array}{l}\text { WGA, } \\
\mathrm{kg} / \mathrm{ha}\end{array}$ & $\begin{array}{l}\mathrm{CWG} \\
\mathrm{kg} / \mathrm{ha}\end{array}$ \\
\hline Treatment & & & & & \\
CS & 428.4 & 0.626 & $1243.10^{\mathrm{a}}$ & $129.11^{\mathrm{a}}$ & $64.55^{\mathrm{a}}$ \\
ILF-1 & 435.2 & 0.554 & $1085.50^{\mathrm{b}}$ & $98.50^{\mathrm{ab}}$ & $49.25^{\mathrm{ab}}$ \\
ILF-2 & 435.2 & 0.570 & $982.68^{\mathrm{b}}$ & $77.93^{\mathrm{b}}$ & $38.97^{\mathrm{b}}$ \\
SE & 4.530 & 0.023 & 49.713 & 10.092 & 5.046 \\
$P$-value & 0.928 & 0.553 & 0.009 & 0.044 & 0.044 \\
\hline
\end{tabular}

${ }^{a b}$ - means with different superscripts in the same column are significantly different from each other according to the Tukey test $(P<0.05)$; SE - standard error

per hectare, carcass weight gain per hectare and stocking rate (Table 3 ). Weight gain per hectare and carcass weight gain per hectare were higher in CS and lower in ILF-2. On the other hand, ILF-1 did not differ from other treatments. The stocking rate was higher in CS and equal between ILF-1 and ILF-2. The forage dry mass equaled 3106, 2500 and $2496 \mathrm{~kg} / \mathrm{ha}$ for CS, ILF-1 and ILF-2, respectively, which did not differ between treatments $(P=0.473)$. However, the higher numerical value found for CS possibly contributed to the higher SR, and consequently, higher WGA in this system.

Data referring to microclimate variables and thermal comfort are shown in Table 4. Measurements of WS, AT, RH, GT, THI and black globe temperature and GTHI found in CS differed from those of ILF-1 and ILF-2 systems $(P<0.05)$. Among these variables, higher values for WS, AT, GT, THI and GTHI were observed in the

Table 4. Wind speed (WS), ambient temperature (AT), relative humidity $(\mathrm{RH})$ of the air, globe temperature $(\mathrm{GT})$, temperature and humidity index (THI) and black globe temperature and humidity index (GTHI) in conventional system (CS), integrated livestock forest system with a density of 187 (ILF-1) and 446 (ILF-2) trees/ha

\begin{tabular}{|c|c|c|c|c|c|c|}
\hline Indices & $\begin{array}{l}\text { WS, } \\
\mathrm{ms}^{-1}\end{array}$ & $\begin{array}{l}\text { AT, } \\
{ }^{\circ} \mathrm{C}\end{array}$ & $\begin{array}{l}\mathrm{RH}, \\
\%\end{array}$ & GT & THI & GTHI \\
\hline \multicolumn{7}{|c|}{ Treatment } \\
\hline CS & $1.39^{a}$ & $26.58^{a}$ & $54.97^{b}$ & $30.47^{a}$ & $73.96^{a}$ & $77.78^{a}$ \\
\hline ILF-1 & $1.02^{b}$ & $25.01^{b}$ & $58.06^{a}$ & $27.30^{b}$ & $72.25^{b}$ & $74.56^{b}$ \\
\hline ILF-2 & $1.00^{\mathrm{b}}$ & $24.78^{b}$ & $58.56^{a}$ & $26.91^{b}$ & $72.07^{\mathrm{b}}$ & $74.17^{b}$ \\
\hline SE & 0.077 & 0.179 & 0.701 & 0.260 & 0.173 & 0.255 \\
\hline$P$-value & 0.0073 & $<0001$ & $<0001$ & $<0001$ & $<0001$ & $<0001$ \\
\hline
\end{tabular}

Table 5. Hot carcass weight (HCW), carcass yield (CY), visceral fat weight (VFW), subcutaneous fat thickness (SFT), rib eye area (REA) and marbling (MAR) of Angus-Nellore heifers kept in a conventional system (CS), integrated livestock forest system with a density of 187 (ILF-1) and 446 (ILF-2) trees/ha

\begin{tabular}{lllllll}
\hline Indices & $\begin{array}{l}\mathrm{HCW}, \\
\mathrm{kg}\end{array}$ & $\begin{array}{l}\mathrm{CY}, \\
\%\end{array}$ & $\begin{array}{l}\mathrm{VFW}, \\
\mathrm{kg}\end{array}$ & $\begin{array}{l}\mathrm{SFT}, \\
\mathrm{mm}\end{array}$ & $\begin{array}{l}\mathrm{REA}, \\
\mathrm{cm}\end{array}$ & $\begin{array}{l}\mathrm{MAR}, \\
1-10\end{array}$ \\
\hline Treatment & & & & & & \\
CS & 216.3 & 50.50 & 4.52 & 5.50 & 96.04 & 4.90 \\
ILF-1 & 216.7 & 49.80 & 4.32 & 5.13 & 91.03 & 4.91 \\
$\quad$ ILF-2 & 217.9 & 50.06 & 3.99 & 5.88 & 92.83 & 5.14 \\
SE & 3.219 & 0.239 & 0.121 & 0.216 & 1.522 & 0.082 \\
$P$-value & 0.780 & 0.468 & 0.490 & 0.670 & 0.550 & 0.381 \\
\hline
\end{tabular}

SE - standard error

system without trees. On the other hand, RH was higher in systems that had the arboreal component.

Regarding the carcass quality of the animals, it was observed that the carcass weight and yield were not influenced by the systems $(P>0.05)$, which possibly contributed to the absence of difference between treatments for REA, SFT, visceral fat weight (VFW) and MAR (Table 5).

The data on the approximate composition of the meat revealed that there was difference only for the protein $(P<0.05)$, which showed smaller amount in the ILF-2 system in comparison to other systems (Table 6). In addition, among the analysed physical variables, difference was observed only for $\mathrm{pH}$, which showed lower average value in the ILF-1 system than in ILF-2 system $(P<0.05)$. However, both did not differ from CS. No differences were found between treatments in terms of cooking weight loss, shear strength and collagen $(P>0.05$; Table 7).

Table 6. Protein, ethereal extract, moisture and ashes content in the longissimus thoracis muscle of Angus-Nellore heifers kept in a conventional system (CS), integrated livestock forest system with a density of 187 (ILF-1) and 446 (ILF-2) trees/ha, \%

\begin{tabular}{lcccc}
\hline Indices & Protein & $\begin{array}{l}\text { Ethereal } \\
\text { extract }\end{array}$ & Moisture & Ashes \\
\hline Treatment & & & & \\
CS & $23.09^{\mathrm{a}}$ & 1.83 & 73.78 & 1.22 \\
ILF-1 & $23.07^{\mathrm{a}}$ & 2.10 & 73.61 & 1.29 \\
ILF-2 & $22.73^{\mathrm{b}}$ & 2.11 & 73.90 & 1.26 \\
SE & 0.058 & 0.078 & 0.104 & 0.014 \\
$P$-value & 0.023 & 0.244 & 0.659 & 0.321 \\
\hline
\end{tabular}

ab - means with different superscripts in the same column are significantly different from each other according to the Tukey test $(P<0.05)$; SE - standard error 
Table 7. Potential of hydrogen (pH), weight loss by cooking (WLC), shear force $(S F)$, collagen, luminosity $\left(L^{*}\right)$, red intensity $\left(a^{*}\right)$, yellow intensity $\left(b^{*}\right)$, hue angle $\left(H^{*}\right)$ and oxymyoglobin/metmyoglobin (O/M) of the longissimus thoracis muscle of Angus-Nellore heifers kept in a conventional system (CS), integrated livestock forest system with a density of 187 (ILF-1) and 446 (ILF-2) trees/ha

\begin{tabular}{lrrrrl}
\hline \multirow{2}{*}{ Indices } & \multicolumn{2}{l}{ Treatment } & \multicolumn{2}{l}{ SE } & $P$-value \\
\cline { 2 - 5 } & \multicolumn{1}{c}{ CS } & \multicolumn{1}{c}{ ILF-1 } & \multicolumn{1}{c}{ ILF-2 } & & \\
\hline pH & $5.80^{\mathrm{ab}}$ & $5.75^{\mathrm{a}}$ & $5.83^{\mathrm{b}}$ & 0.011 & 0.037 \\
WLC, \% & 21.39 & 24.94 & 23.39 & 0.693 & 0.056 \\
SF, $N$ & 48.45 & 54.00 & 49.86 & 1.812 & 0.473 \\
Collagen, \% & 1.37 & 1.42 & 1.37 & 0.018 & 0.403 \\
$L^{*}$ & 35.47 & 34.25 & 35.33 & 0.306 & 0.298 \\
$a^{*}$ & 14.97 & 15.93 & 15.70 & 0.281 & 0.279 \\
$b^{*}$ & 6.42 & 7.03 & 6.75 & 0.203 & 0.435 \\
$H^{*}$ & 23.11 & 23.54 & 22.46 & 0.377 & 0.519 \\
O/M & 2.46 & 2.33 & 2.40 & 0.050 & 0.638 \\
\hline
\end{tabular}

ab - means with different superscripts in the same line are significantly different from each other according to the Tukey test $(P<0.05)$; SE - standard error

\section{Discussion}

In relation to performance, it was observed that animals form CS had a higher stocking rate and obtained greater weight gain per ha and, consequently, greater carcass weight gain per hectare in comparison to systems with trees, due to the greater amount of dry forage mass present in this system.

However, it was observed that the ILF-1 system did not differ from the CS, possibly due to the smaller area occupied by the eucalyptus trees in this lower density system (8\%), unlike ILF-2, where eucalyptus occupies $28 \%$ of the paddock area, thus reducing the useful pasture area and affecting the stocking rate, weight gain per hectare and carcass weight gain per hectare. Despite the lower productivity per area in the integration system with a higher density of trees, it must be noted that, if trees are cut, the treatment with the highest density will contribute with higher income per hectare thanks to the sale of wood.

The microclimate variables and the thermal comfort indexes were better in the systems with trees (ILF-1 and ILF-2), which presented lower AT, GT, THI and GTHI, reinforcing the importance of this component for the improvement of the thermal comfort of the animals. However, this improvement in animal welfare did not contribute to significant weight gains for the animals. Likewise, in a study carried on Nellore cattle kept in integrated crop livestock system, integrated crop livestock forest system with density of 196 trees/ha and integrated crop-livestock-forest system with density 448 of trees/ha in the same area (CLI, CLFI-1 and CLFI-2, respectively), there was improvement in the welfare of animals kept under shade compared to those submitted to full sun. However, there was no difference in weight gain by area and ADG, which is explained by the reduction in the amount of forage mass in relation to the integrated crop-livestock system (Aranha et al., 2019).

Regarding the carcass, the analysed variables did not show any difference between treatments, since the ADG and the final live weight did not differ between systems. This fact was observed in Nellore animals kept in integrated crop-livestock systems and evaluated in the same area of the present study (Luz et al., 2019).

It is observed that the hot carcass weight (Table 5) in all treatments reached a value above the minimum of $180 \mathrm{~kg}$ for females, which is standard set in the Brazilian market for this category (Ministry of Agriculture, 2004). Likewise, the value found for carcass yield in all treatments can also be considered satisfactory, as many slaughterhouses consider only $50 \%$ of carcass yield when buying the animal based on its live weight (Lopes et al., 2012).

Regarding REA, Taurine breeds tend to have higher REA in relation to Zebu cattle, as they have higher growth rates (Lopes et al., 2012). Crossbred Angus-Nellore animals from all experimental groups in this study obtained rib area values above $75 \mathrm{~cm}^{2}$, which placed them among animals with high yield of meat cuts (Luchiari Filho, 2000).

On the other hand, CS animals were expected to have increased deposition of visceral and intramuscular fat (MAR) and reduced subcutaneous fat deposit, which is metabolic strategy used by the animals for greater heat dissipation (Gregory, 2010). Although the animals in the systems with shadow have better microclimate conditions, it is suggested that the absence of difference for the characteristics of fat thickness and MAR was due to the milder average values of the ambient temperature in the finishing phase of the animals, which is the phase that corresponds to greater deposition of these fats (Turini et al., 2015).

In addition, MAR in all systems was considered modest. Although heifers received supplementation $(0.7 \%$ of LW) and presented satisfactory ADG in all treatments, the amount of supplement combined with low dry forage mass did not provide a greater degree of marbling and, consequently, did not increase the percentage of ethereal extract in the meat tissue. 
Among the variables associated with the centesimal composition of the meat, the difference was found only for the protein content, which was lower in the ILF-2 system. The percentage of meat protein is inversely proportional to the amount of fat and, although there was no difference in the ether extract between the treatments, numerically speaking the amount of ether extract was higher in ILF-2, which may have influenced the lower percentage of protein (Zundt, 2003). However, even with this difference, the protein content was within the range that is considered adequate for meat (20\%) (Huff-Lonergan and Lonergan, 2005).

Weight loss by cooking, SF, collagen, $L^{*}, a^{*}$, $b^{*}, H^{*}$, as well as oxymyoglobin and metmioglobina $(\mathrm{O} / \mathrm{M})$ of the longissimus thoracis muscle of Angus-Nellore heifers kept in conventional and integrated livestock forest systems did not differ between the evaluated options.

However, the $\mathrm{pH}$ was lower in the ILF-1 treatment and higher in the ILF-2, which did not differ from the CS. However, the difference in $\mathrm{pH}$ between treatments was not big enough to affect the evaluated qualitative parameters, possibly because it was within the range recommended in the literature (5.5 to 5.7; Kandeepan and Biswas, 2007).

In the same way, the SF found in all systems classifies the meat as soft, since the values are close to those found in the literature for this classification (40.13 $N$ and $44.7 N$ according to Rodas González et al. (2009) and Johnson et al. (1988), respectively).

The colour of the meat is directly related to the $\mathrm{pH}$ value after cooling. In this study, the $\mathrm{pH}$ values remained within the ideal ranges, the characteristics of $L^{*}, a^{*}$ and $b^{*}$ were also adequate $\left(L^{*}=33.2-\right.$ 41.0, $a^{*}=11.1-23.6$ and $b^{*}=6.1-11.3$ ) (Muchenje et al., 2009), classifying the meat as suitable for human consumption. The $\mathrm{O} / \mathrm{M}$ values and $H^{*}$ were also consistent with those found in studies with beef (Luz et al., 2019).

\section{Conclusions}

The system with lower tree density (ILF-1) does not interfere with the performance and carcass characteristics of Angus-Nellore heifers finished with the use of supplementation in integrated livestock forest systems. However, when using the system with higher density tree (ILF-2), the weight gain per hectare, the carcass weight gain per hectare and the stocking rate were reduced.

The systems with trees improve the microclimate variables and the indices of thermal comfort in relation to the conventional system. In addition, the introduction of trees in the system does not interfere with the carcass and meat quality of Angus-Nellore heifers, which remain within the quality standards and are suitable for human consumption.

\section{Founding}

Research Foundation of the State of São Paulo FAPESP for support of the research and Coordination for the Improvement of Higher Education Personnel (CAPES) for the scholarship.

\section{Conflict of interest}

Authors declare that there is no conflict of interest.

\section{References}

AMSA (American Meat Science Association), 1995. Research Guidelines for Cookery Sensory Evaluation, and Instrumental Tenderness Measurement of Fresh Meat. AMSA \& National Live Stock and Meat Board. Chicago IL, (USA)

ANUALPEC, 2018. Brazilian Livestock Yearbook (in Portuguese: Anuário da pecuária brasileira). FNP Consultoria/Agros Comunicação. São Paulo (Brazil)

AOAC International, 2012. Official Methods of Analysis of AOAC International. 19th Edition. Gaithersburg, MD (USA)

AOAC International, 2007. Official Methods of Analysis of AOAC International. Current through revision 2. $18^{\text {th }}$ Edition. Gaithersburg, MD (USA)

Aranha H.S., Andrighetto C., Lupatini G.C., Bueno L.G.F., Trivelin G.A., Mateus G.P., Luz P.A.C., Santos J.M.F., Sekiya B.M.S. Vaz R.F., 2019. Production and thermal comfort of Nellore beef cattle finished in integrated crop-livestock systems (in Portuguese). Arq. Bras. Med. Vet. Zootecn. 71, 1686-1694, https://doi.org/10.1590/1678-4162-9913

Béltran J.A., Jaime I., Santolaria P., Sañudo C., Albertí P., Roncalés P., 1997. Effect of stress-induced high post-mortem pH on protease activity and tenderness of beef. Meat Sci. 45, 201-207, https://doi.org/10.1016/S0309-1740(96)00103-9

Buffington D.E., Collazo-Arocho A., Canton G.H., Pitt D., Thatcher W.W., Collier R.J., 1981. Black globe-humidity index (BGHI) as comfort equation for dairy cows. Trans ASAE 24, 711-714, https://doi.org/10.13031/2013.34325

Crusciol C.A.C., Nascente A.S., Mateus G.P., Pariz C.M., Martins P.O., Borghi E., 2014. Intercropping soybean and palisade grass for enhanced land use efficiency and revenue in a no till system. Eur. J. Agron. 58, 53-62, https://doi.org/10.1016/j. eja.2014.05.001

Euclides V.P.B., Montagner D.B., Barbosa R.A., Nantes N.N., 2014. Pasture and grazing management of Brachiaria brizantha (Hochst) Stapf and Panicum maximum Jacq (in Portuguese). Rev. Ceres 61, Suppl., 808-818, https://doi.org/10.1590/0034737×201461000006

Gregory N.G., 2010. How climatic changes could affect meat quality. Food Res. Int. 43, 1866-1873, https://doi.org/10.1016/j. foodres.2009.05.018 
Honikel K.O., 1998. Reference methods for the assessment of physical characteristics of meat. Meat Sci. 49, 447-457, https://doi. org/10.1016/S0309-1740(98)00034-5

Huff-Lonergan E., Lonergan S.M., 2005. Mechanisms of water-holding capacity of meat: the role of postmortem biochemical and structural changes. Meat Sci. 71, 194-204, https://doi. org/10.1016/j.meatsci.2005.04.022

Johnson D.D., Lunt D.K., Savell J.W., Smith G.C., 1988. Factors affecting carcass characteristics and palatability of young bulls. J. Anim. Sci. 66, 2568-2577, https://doi.org/10.2527/ jas1988.66102568x

Johnson A.D., 1978. Sample preparation and chemical analysis of vegetation. In: L. t' Mannetje (Editor). Measurement of Grassland Vegetation and Animal Production. Commonwealth Agricultural Bureaux. Aberustwyth (UK), pp. 96-102

Kandeepan G., Biswas S., 2007. Effect of low temperature preservation on quality and shelf life of buffalo meat. Am. J. Food Technol. 2, 126-135, https://doi.org/10.3923/ajft.2007.126.135

Lopes L.S., Ladeira M.M., Machado Neto O.R., Paulino V.R., Chizzotti M.L., Ramos E.M., Oliveira D.M., 2012. Characteristics of carcass and commercial meat cuts from Red Norte and Nellore young bulls finished in feedlot (in Portuguese). Rev. Bras. Zootecn. 41, 970-977, https://doi.org/10.1590/S151635982012000400020

Luchiari Filho A., 2000. Livestock of beef (in Portuguese: Pecuária da carne bovina). Linbife, Albino Luchiari Filho, São Paulo (Brazil)

Luz P.A.C., Andrighetto C., Lupatini G.C., Aranha H.S., Trivelin G.A., Mateus G.P., Santos C.T., Francisco C.L., Castilhos A.M., Jorge A.M., 2019. Effect of integrated crop-livestock systems in carcass and meat quality of Nellore cattle. Livest. Sci. 220, 83-92, https://doi.org/10.1016/j.livsci.2018.11.018

MacDougall D.B., 1994. Colour meat. In: A.M. Pearson, T.R. Dutson (Editors). Quality Attributes and their Measurement in Meat, Poultry and Fish Products. Advances in Meat Research, vol. 9. Springer. Boston, MA (USA), pp. 79-93, https://doi. org/10.1007/978-1-4615-2167-9_3

Ministry of Agriculture, 2004. Normative Instruction No. 9, of May 4, 2004. Livestock and Supply. Brazilian Bovine Carcass Classification System (in Portuguese: Instrução Normativa № 9 , de 4 de maio de 2004; Pecuária e Abastecimento. Sistema Brasileiro de Classificação de Carcaças de Bovinos), https:// www.defesa.agricultura.sp.gov.br/legislacoes/instrucao-normativa-9-de-04-05-2004,643.html

Mott G.O., Lucas H.L., 1952. The design, conduct, and interpretation of grazing trials on cultivated and improved pastures. In: Proceedings from $6^{\text {th }}$ International Grassland Congress. Pennsylvania State College, PA (USA), pp. 1380-1385
Muchenje V., Dzama K., Chimonyo M., Strydom P.E., Hugo A., Raats J.G., 2009. Some biochemical aspects pertaining to beef eating quality and consumer health: a review. Food Chem. 112, 279-289, https://doi.org/10.1016/j.foodchem.2008.05.103

Olivo R., Shimokomaki M., 2001. Meat: on the path of research (in Portuguese: Carnes: no caminho da pesquisa). Ver Curiosidades. Cocal do Sul (Brazil)

Pereira J.R.M., Montagner M.M., Fluck A.C., Santiago A.P., Abbado Neres M., 2017. Climate effects about physiology on beef cattle Bos taurus $\times$ Bos indicus (in Portuguese). REDVET Rev. Elect. Vet. 18, 1-13, https://www.redalyc.org/ pdf/636/63653574008.pdf

Rodas-González A., Huerta-Leidenz N., Jerez-Timaure N., Miller M.F., 2009. Establishing tenderness thresholds of Venezuelan beef steaks using consumer and trained sensory panels. Meat Sci. 83, 218-223, https://doi.org/10.1016/j.meatsci.2009.04.021

Thom E.C., 1959. The discomfort index. Weatherwise, 12, 57-61, https://doi.org/10.1080/00431672.1959.9926960

Turini T., Ribeiro E.L.A., Alves S.J., Mizubuti I.Y., Silva L.D.F., 2015. Performance of intact and castrated beef cattle in an intensive croppasture rotation system (in Portuguese). Ciênc. Agrár. 36(3), Suppl. 1, 2339-2351, https://doi.org/10.5433/16790359.2015v36n3Supl1p2339

USDA, 2017. United States Standards for grades of beef carcass. https://www.ams.usda.gov/sites/default/files/media/CarcassBeefStandard.pdf

Van Raij B., Cantarella H., Quaggio J.A., Furlani A.M.C. (Editors), 1997. Fertilization and liming recommendations for the State of São Paulo (in Portuguese: Recomendações de adubação e calagem para o Estado de São Paulo). $2^{\text {nd }}$ Edition Revised and Updated. Campinas, Instituto Agronômico/Fundação IAC. São Paulo (Brazil)

Wirsenius S., Azar C., Berndes G., 2010. How much land is needed for global food production under scenarios of dietary chances and livestock productivity increases in 2030 ? Agric. Sys. 103, 621-638, https://doi.org/10.1016/j.agsy.2010.07.005

Zundt M., Macedo F.A.F., Martins E.N., Mexia A.A., Martin Nieto L., Yamamoto S.M., Macedo R.M.G., 2003. Carcass characteristics of lambs finished in drylot with diets contend different protein levels (in Portuguese). Cienc. Rural 33, 565557, https://doi.org/10.1590/S0103-84782003000300027 